\title{
Produksi dan Kualitas Benih Kedelai dalam Sistem Produksi Bersih
}

\section{Production and Quality of Soybean Seed from Zero Waste Production System}

\author{
Rudi Hartawan $^{1 *}$, Yulistiati Nengsih ${ }^{1}$, dan Edy Marwan² \\ ${ }^{1}$ Program Studi Agroteknologi, Fakultas Pertanian, Universitas Batanghari \\ Jl. Slamet Riyadi, Broni, Kota Jambi, 36122, Indonesia \\ ${ }^{2}$ Prodi Agribisnis, Fakultas Pertanian, Universitas Muhammadiyah Bengkulu \\ Jl. Bali Bengkulu, 38119, Indonesia
}

Diterima 26 November 2017/Disetujui 30 Juli 2018

\begin{abstract}
Production of high quality seed is one of the key factors for soybean self-sufficiency. The study was aimed to produce high quality soybean seed from zero waste system. The trial was carried out at Sebapo Experimental Station, Jambi, Center for Agricultural Post Harvest Research and Development, and Center for Agricultural Land Resources Research and Development, The Ministry of Agriculture, Bogor, from January until October 2017. The experiment used a complete randomized design with a treatments combination both organic nutrient of composted soybean litter ( 5 tons $\mathrm{h}^{-1}$ ) and inorganic nutrient (25 kg Nitrogen ha-, $50 \mathrm{~kg} \mathrm{P}_{2} \mathrm{O}_{5} \mathrm{ha}^{-1}$, and $50 \mathrm{~kg} \mathrm{~K} \mathrm{O} \mathrm{ha}^{-1}$ ). The treatments were designed as follow : $\mathrm{K}_{0}$ (control), $\mathrm{K}_{1}$ (100\% organic), $K_{2}\left(75 \%\right.$ organic $+25 \%$ inorganic), $K_{3}(50 \%$ organic $+50 \%$ inorganic $), K_{4}(25 \%$ organic $+75 \%$ inorganic $)$, and $K_{5}\left(100 \%\right.$ inorganic). The results showed that the treatment $K_{3}$ produced the highest seed production $\left(1.72\right.$ tons ha $\left.{ }^{-1}\right)$ and the highest 1,000 seed weight (147.71 g). After 3 months storage at room temperature, the seed with treatment $K_{3}$ could maintain its quality with indicator 1,000 seed weight (140.98 g), $10.82 \%$ water content, $34.98 \%$ protein content, $57.42 \mu \mathrm{Scm}$ ${ }^{1} g^{-1}$ electrical conductivity, $80.98 \%$ germination percentage and $27.48 \%$ etmal $^{-1}$ rate of germination speed.
\end{abstract}

Keywords: Compost, litter, seed technology

\section{ABSTRAK}

Produksi benih bermutu merupakan salah satu faktor kunci untuk menunjang swasembada kedelai. Penelitian bertujuan untuk menghasilkan benih kedelai bermutu dari sistem produksi bersih. Percobaan telah dilakukan di Balai Benih Induk Palawija Sebapo, Jambi, Balai Besar Penelitian dan Pengembangan Pascapanen Pertanian, dan Balai Besar Penelitian dan Pengembangan Sumberdaya Lahan Pertanian, Kementerian Pertanian di Bogor pada bulan Januari sampai Oktober 2017. Percobaan menggunakan rancangan lingkungan acak lengkap satu faktor dengan rancangan perlakuan kombinasi hara organik dari kompos serasah kedelai (5 ton ha-1) dan hara anorganik (25 $\mathrm{kg}$ Nitrogen ha-1 $50 \mathrm{~kg} \mathrm{P}_{2} \mathrm{O}_{5} \mathrm{ha}^{-1}$, dan 50 $\mathrm{kg} \mathrm{K}_{2} \mathrm{O} \mathrm{ha} \mathrm{h}^{-1}$ ). Perlakuan disusun sebagai berikut: $K_{0}$ (kontrol), $K_{1}\left(100 \%\right.$ organik), $K_{2}(75 \%$ organik $+25 \%$ anorganik), $K_{3}\left(50 \%\right.$ organik $+50 \%$ anorganik), $K_{4}\left(25 \%\right.$ organik $+75 \%$ anorganik), dan $K_{5}(100 \%$ anorganik $)$. Hasil percobaan menunjukkan perlakuan $K_{3}$ menghasilkan produksi benih tertinggi $\left(1.72\right.$ ton ha $\left.{ }^{-1}\right)$ dan bobot 1,000 butir tertinggi $(147.71 \mathrm{~g})$. Setelah penyimpanan selama 3 bulan pada suhu kamar, benih dari tanaman dengan perlakuan $K_{3}$ dapat mempertahankan kualitasnya dengan indikator bobot 1,000 butir benih $140.98 \mathrm{~g}$, kadar air 10.82\%, kandungan protein 34.98\%, daya hantar listrik $57.42 \mu \mathrm{Scm}^{-1} \mathrm{~g}^{-1}$, daya berkecambah $80.98 \%$, dan kecepatan tumbuh $27.48 \% \mathrm{etmal}^{-1}$.

Kata kunci: Kompos, serasah, teknologi benih

\section{PENDAHULUAN}

Produksi benih kedelai menempati posisi yang penting bila dikaitkan dengan upaya meningkatkan produktivitas guna mewujudkan swasembada kedelai. Saat ini kebutuhan kedelai nasional mencapai 2.3 juta ton per tahun (Balai

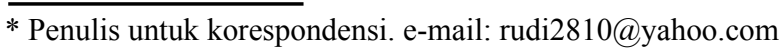

Penelitian Tanaman Aneka Kacang dan Umbi, 2018). Selanjutnya dinyatakan bahwa pada tahun 2018 dialokasikan lahan pertanaman kedelai seluas 2 juta hektar. Jika setiap hektar memerlukan $40 \mathrm{~kg}$ benih bermutu, maka kebutuhan benih kedelai tahun tersebut sebanyak 80,000 ton.

Produksi benih kedelai yang mengandalkan pupuk anorganik telah banyak dilakukan dan memberikan hasil yang baik. Kelemahan penggunaan pupuk anorganik adalah tidak ramah lingkungan. Kegiatan produksi benih kedelai 
menghasilkan sampah (waste) yang terbuang percuma karena tidak dimanfaatkan. Pada umumnya sampah ini dibakar karena dianggap sebagai limbah (Hartawan et al., 2017). Pemanfaatan sampah dari kegiatan produksi benih kedelai diharapkan dapat mengurangi penggunaan pupuk anorganik.

Sampah hasil sampingan dalam produksi benih kedelai adalah serasah (potongan-potongan kecil batang, ranting, dan polong). Serasah ini langsung terbentuk saat dilakukan perontokan benih. Penelitian pendahuluan yang dilaksanakan oleh Hartawan et al. (2017) menunjukkan dalam satu hektar lahan kedelai dihasilkan sebanyak 0.5 ton serasah. Kandungan hara serasah kedelai adalah $0.55 \%$ atau $2.75 \mathrm{~kg}$ Nitrogen $(\mathrm{N}), 0.23 \%$ atau $1.15 \mathrm{~kg}$ Fosfor $\left(\mathrm{P}_{2} \mathrm{O}_{5}\right)$, dan $0.30 \%$ atau $1.50 \mathrm{~kg}$ Kalium $\left(\mathrm{K}_{2} \mathrm{O}\right)$. Hasil penelitian tersebut juga menunjukkan bahwa kandungan hara kompos yang berasal dari serasah kedelai adalah; $0.6 \% \mathrm{~N}, 0.25 \%$ $\mathrm{P}_{2} \mathrm{O}_{5}$ total, $0.34 \% \mathrm{~K}_{2} \mathrm{O}$ total, rasio $\mathrm{C} / \mathrm{N} 18$, kadar air $46 \%$, dan $\mathrm{pH} 6$ sampai 7. Kandungan hara ini berpotensi sebagai fortifikasi untuk menurunkan penggunaan pupuk anorganik. Penggunaan serasah dari hasil panen ini merupakan sebuah prinsip dari produksi bersih dalam produksi benih kedelai.

Penggunaan hara organik untuk produksi kedelai telah banyak dilaporkan dan memberikan hasil yang baik (Nkoa et al., 2014; Yagoub et al., 2015; Shaheen et al., 2017). Penggunaan hara organik dalam produksi benih memerlukan sebuah pengkajian yang cermat guna mengetahui mutu benih yang dihasilkan serta kemampuannya bertahan pada penyimpanan alami. Hasil penelitian Garud et al. (2014) mengindikasikan bahwa protein berperan dalam menjaga konsistensi mutu benih kedelai dalam penyimpanan. Penelitian Noviana et al. (2016) mendapatkan bahwa kebocoran ion berkorelasi nyata dengan kemunduran benih kedelai yang disimpan dalam ruang terkendali. Protein pada membran akan menjaga konsistensi dan menghambat laju kebocoran ion. Menurut Mattioni et al. (2015) kebocoran ion merupakan salah satu indikator mutu benih.

Penggunaan hara organik tidak serta merta menghasilkan benih dengan kualitas yang tinggi. Perlu dicari kombinasi-kombinasi yang tepat, dimulai dari pengomposan serasah batang dan polong kedelai, persentase substitusi hara anorganik dengan kompos serasah sehingga didapatkan benih dengan kualitas yang tinggi dan mampu bertahan dalam penyimpanan alami.

\section{BAHAN DAN METODE}

Penelitian dilaksanakan selama 10 bulan dari Januari sampai Oktober 2017 di Balai Benih Induk Sebapo, Muaro Jambi. Pengujian benih dilaksanakan di Laboratorium Dasar Universitas Batanghari. Pengujian protein di Balai Besar Penelitian dan Pengembangan Pascapanen Pertanian, Kementerian Pertanian di Bogor. Pengujian kualitas kompos dilakukan di Balai Besar Penelitian dan Pengembangan Sumberdaya Lahan Pertanian, Kementerian Pertanian di Bogor.

Percobaan menggunakan rancangan lingkungan acak lengkap satu faktor dengan tiga ulangan. Rancangan perlakuan kombinasi pupuk organik (berasal dari serasah kedelai) dan anorganik. Dosis pupuk organik adalah 5 ton $\mathrm{ha}^{-1}$. Dosis pupuk anorganik $100 \%$ adalah $25 \mathrm{~kg}$ Nitrogen $\mathrm{ha}^{-1}, 50 \mathrm{~kg} \mathrm{P}_{2} \mathrm{O}_{5}$ ha $^{-1}$, dan $50 \mathrm{~kg} \mathrm{~K}_{2} \mathrm{O}$ ha $^{-1}$. Kombinasi pupuk organik dan anorganik $(\mathrm{K})$ disusun sebagai berikut; $\mathrm{K} 0=$ kontrol, $\mathrm{K} 1=100 \%$ pupuk organik, $\mathrm{K} 2=75 \%$ pupuk organik $+25 \%$ pupuk anorganik, K3 $=50 \%$ pupuk organik $+50 \%$ pupuk anorganik, K4 $=25 \%$ pupuk organik $+75 \%$ pupuk anorganik, dan $\mathrm{K} 5=100 \%$ pupuk anorganik.

\section{Pembuatan Kompos}

Pengomposan menggunakan metode wind row system seperti yang dijelaskan oleh Kurnia et al. (2017). Serasah kedelai dikomposkan dengan perlakuan $450 \mathrm{ml} \mathrm{EM}_{4}$ per 10 $\mathrm{kg}$ serasah dan dikomposkan selama 2 bulan. Dosis kompos (hara organik) yang digunakan dalam produksi benih kedelai adalah 5 ton $\mathrm{ha}^{-1}$. Kualitas kompos mengacu pada SNI No. 19-7030-2004 dan disajikan pada Tabel 1.

Percobaan dilaksanakan di lapangan pada tanah jenis Ultisol. Masing-masing petak percobaan berukuran $4.5 \mathrm{~m}$ x $4.5 \mathrm{~m}$. Pemberian hara organik sesuai dengan perlakuan dilakukan pada saat pengolahan tanah. Bahan tanam yang digunakan adalah benih kedelai varitas Anjasmoro yang didapat dari BPSB TPH Provinsi Jambi. Benih ditanam dengan jarak tanam $40 \mathrm{~cm}$ x $15 \mathrm{~cm}$. Perlakuan hara anorganik dilakukan saat tanam secara larikan. Seleksi tanaman terbaik dilakukan pada umur 14 hari setelah tanam dan dipilih dua tanaman. Metode panen dan pasca panen mengacu pada SNI 01-6234.4-2003. Hasil panen digrading menggunakan ayakan dengan diameter 4 sampai $8 \mathrm{~mm}$.

Tabel 1. Kualitas kompos serasah kedelai dengan perlakuan $450 \mathrm{~mL} \mathrm{EM}_{4}$ per $10 \mathrm{~kg}$ serasah dan dikomposkan selama 2 bulan

\begin{tabular}{lccccccc}
\hline Kompos & \multicolumn{9}{c}{ Kualitas } \\
\cline { 2 - 9 } $\begin{array}{l}\text { serasah } \\
\text { kedelai }\end{array}$ & $\mathrm{pH}$ & Kadar air (\%) & $\mathrm{P}_{2} \mathrm{O}_{5}(\%)$ & $\mathrm{K}_{2} \mathrm{O}(\%)$ & N- total (\%) & C-total (\%) & Rasio C/N \\
\cline { 2 - 9 } & 7.20 & 42.00 & 0.30 & 0.38 & 0.75 & 11.50 & 15.33 \\
\hline Min.*. & 6.80 & - & 0.10 & 0.20 & 0.40 & 9.80 & 10.00 \\
Maks.*. & 7.49 & 50.00 & - & - & - & 32.00 & 20.00 \\
\hline
\end{tabular}

Keterangan: *berdasarkan SNI: 19-7030-2004 
Biji kedelai yang lolos pada diameter $4 \mathrm{~mm}$ tidak dihitung sebagai benih. Benih dikeringkan dengan sinar matahari sampai kadar air 10\%. Benih dibungkus dengan plastik high density poly etilen (HDPE) lalu disimpan dalam ruangan pada kelembaban $65 \%$ dan suhu antara 25 sampai $27^{\circ} \mathrm{C}$ selama 3 bulan.

Peubah yang diamati adalah indeks luas daun (ILD), laju asimilasi bersih (LAB), dan laju tumbuh relatif (LTR) pada fase berbunga aktif (49 hari setelah tanam) dan fase pembentukan dan pengisian polong (70 hari setelah tanam) dengan metode yang dijelaskan oleh Muhammad et al. (2013). Rumus: ILD $=\frac{\text { LA }}{\mathrm{P}}$

dimana ILD adalah indeks luas daun $\left(\mathrm{cm}^{2} \mathrm{~cm}^{-2}\right)$; LA adalah luas daun total dan $\mathrm{P}$ adalah luas areal pertanaman.

Rumus: $\mathrm{LAB}=\frac{\mathrm{W} 2-\mathrm{W} 1}{\mathrm{~T} 2-\mathrm{T} 1} \times \frac{\mathrm{LnA} 2-\mathrm{LnA} 1}{\mathrm{LA} 2-\mathrm{LA} 1}$

dimana LAB adalah laju asimilasi bersih $\left(\mathrm{mg} \mathrm{cm}^{-2}\right.$ hari $\left.^{-1}\right)$; $\mathrm{W}_{1}$ adalah bobot kering total saat $\mathrm{T}_{1} ; \mathrm{W}_{2}$ adalah bobot kering total saat $\mathrm{T}_{2}, \mathrm{~T}_{1}$ adalah pengukuran waktu 1 ; dan $\mathrm{T}_{2}$ adalah pengukuran waktu $2 ; \mathrm{LA}_{1}$ adalah total luas daun saat pengukuran 1; $\mathrm{LA}_{2}$ adalah total luas daun saat pengukuran 2; dan Ln adalah logaritma natural.

Rumus: $\mathrm{LTR}=\frac{1}{\mathrm{P}} \times \frac{\mathrm{W} 2-\mathrm{W} 1}{\mathrm{~T} 2-\mathrm{T} 1}$

dimana LTR adalah laju tumbuh relatif $\left(\mathrm{mg} \mathrm{g}^{-1}\right.$ hari $\left.^{-1}\right) ; \mathrm{P}$ adalah luas area pertanaman; $\mathrm{W}_{1}$ adalah bobot kering total saat $\mathrm{T}_{1} ; \mathrm{W}_{2}$ adalah bobot kering total saat $\mathrm{T}_{2} ; \mathrm{T}_{1}$ adalah pengukuran waktu 1; dan $\mathrm{T}_{2}$ adalah pengukuran waktu 2 .

Peubah produktivitas, bobot 1,000 butir, dan kadar air ditentukan dengan metode gravimetri seperti yang dijelaskan oleh Yagoub et al. (2015). Produktivitas dihitung dengan cara menimbang produksi benih per petak lalu dikonversikan ke satuan hektar. Sampel 1,000 butir benih diambil dari 10 tanaman per petak percobaan. Benih ditentukan bobotnya dengan timbangan analitik.

Kadar air dihitung dengan rumus: $\mathrm{KA}=\frac{(\mathrm{M} 2-\mathrm{M} 3)}{(\mathrm{M} 2-\mathrm{M} 1)} \times 100 \%$

dimana $M_{1}$ adalah berat wadah $(\mathrm{g}), \mathrm{M}_{2}$ adalah berat wadah + isi sebelum pengeringan $(\mathrm{g})$, dan $\mathrm{M}_{3}$ adalah berat wadah + isi setelah pengeringan $(\mathrm{g})$.

Kandungan protein benih diukur dengan metode semi mikro Kjeldhal. Sebanyak $0.50 \mathrm{~g}$ sampel benih dihaluskan dengan grinder lalu dimasukkan ke dalam labu Kjeldahl $100 \mathrm{~mL}$. Sebanyak $25 \mathrm{~mL} \mathrm{H}_{2} \mathrm{SO}_{4}$ pekat dan $2 \mathrm{~g}$ Selenium ditambahkan ke dalam sampel. Dilakukan pemanasan sampai mendidih dan warna larutan menjadi jernih kehijauhijauan. Larutan yang telah dingin diencerkan dalam labu ukur $100 \mathrm{~mL}$. $5 \mathrm{~mL}$ larutan dimasukkan ke dalam alat penyuling lalu tambahkan $5 \mathrm{~mL} \mathrm{NaOH} 30 \%$ serta beberapa tetes indikator PP. Lakukan penyulingan selama 10 menit, kemudian ditampung dalam $10 \mathrm{~mL}$ larutan asam borat $2 \%$ yang telah dicampur indikator. Larutan dititrasi dengan $\mathrm{HCl}$ 0.01 N. Kadar protein dihitung dengan mengkonversikan jumlah nitrogen yang diperoleh.
Protein $(\%)=\frac{(\mathrm{V} 1-\mathrm{V} 2) \times \mathrm{N} \times 0.014 \times \mathrm{fk} \times \mathrm{fp}}{\mathrm{W}} \times 100$

dimana $\mathrm{V}_{1}$ adalah volume $\mathrm{HCl} 0.01 \mathrm{~N}$ yang digunakan untuk titrasi sampel (mL), $\mathrm{V}_{2}$ adalah volume $\mathrm{HCl} 0.01 \mathrm{~N}$ yang digunakan untuk titrasi blanko $(\mathrm{mL}), \mathrm{N}$ adalah normalitas $\mathrm{HCl}, \mathrm{f}_{\mathrm{k}}$ adalah faktor konversi $\mathrm{N}$ pada kedelai (5.75), $\mathrm{f}_{\mathrm{p}}$ adalah faktor pengenceran, dan $\mathrm{W}$ adalah bobot sampel (g).

Kualitas benih diamati sebanyak empat kali yaitu pada $0,1,2$, dan 3 bulan setelah simpan (BSS). Peubah yang diamati adalah bobot 1,000 butir, kadar air, kandungan protein, daya hantar listrik (DHL), daya berkecambah dan kecepatan tumbuh.

Nilai DHL diukur dengan alat electric conductivity meter (Mattioni et al., 2015). Sebanyak 50 butir benih yang telah diketahui beratnya direndam dalam $100 \mathrm{~mL}$ air distilasi selama 24 jam pada suhu kamar.

Rumus yang digunakan adalah: $\mathrm{DHL}=\frac{\mathrm{X}-\mathrm{Y}}{\text { bobot benih }}$

dimana $\mathrm{X}$ adalah DHL air rendaman benih $\left(\mu \mathrm{Scm}^{-1} \mathrm{~g}^{-1}\right), \mathrm{Y}$ adalah DHL blanko $\left(\mu \mathrm{Scm}^{-1} \mathrm{~g}^{-1}\right)$.

Daya berkecambah dan kecepatan tumbuh diukur dengan metode yang dijelaskan oleh Rastegar et al. (2011). Dua puluh butir benih disemai pada media pasir dan diamati maksimal 7 hari lalu dihitung daya kecambahnya dengan rumus sebagai berikut:

Daya Berkecambah $=\frac{\text { Jumlah benih berkecambah normal }}{\text { Jumlah benih yang dikecambahkan }} \times 100 \%$

Kecepatan tumbuh diukur dengan cara menyemai 20 butir benih di lapangan dengan ukuran petak $50 \mathrm{~cm}$ x $50 \mathrm{~cm}$. Kecambah normal yang muncul ke permukaan dihitung setiap 24 jam.

Rumus yang digunakan adalah: $\mathrm{Kct}=\sum_{0}^{t n} \frac{\mathrm{N}}{\mathrm{t}}$

dimana Kct adalah kecepatan tumbuh $\left(\%\right.$ etmal $\left.^{-1}\right)$, $\mathrm{t}$ adalah waktu pengamatan, $\mathrm{N}$ adalah persentase kecambah normal setiap waktu pengamatan dan $t_{n}$ waktu akhir pengamatan. Data dianalisis dengan sidik ragam untuk menentukan perlakuan yang berpengaruh terhadap peubah yang diukur dan selanjutnya dilakukan uji Duncan taraf $\alpha 0.05$.

\section{HASIL DAN PEMBAHASAN}

\section{Produksi Benih}

Pengaturan komposisi hara organik dan anorganik disesuaikan dengan perlakuan. Tujuan penggabungan hara organik dan anorganik ini adalah untuk mengatasi permasalahan kesuburan tanah yang berwawasan lingkungan.

Lahan percobaan di Balai Benih Induk Palawija Sebapo di Muaro Jambi yang digunakan dalam percobaan terkategori miskin hara. Salah satu penyebabnya adalah penggunaan lahan yang terus-menerus dengan menggunakan pupuk anorganik untuk menghasilkan benih palawija. . 
Tabel 2 menunjukkan bahwa lahan percobaan memiliki kejenuhan Aluminium (Al) yang tinggi (53\%) dan $\mathrm{pH}$ yang rendah (5) sehingga hara yang diberikan terjerap oleh ion Al. Sejalan dengan pendapat Muzaiyanah dan Subandi (2016) bahwa lahan-lahan semacam ini memerlukan hara organik untuk memperbaiki struktur tanah, meningkatkan $\mathrm{pH}$ dan menurunkan kejenuhan Al sehingga jerapan terhadap unsur hara dapat dikurangi. Beberapa komponen analisis tanah pada akhir percobaan adalah pH 6.30 (meningkat 26\%), KTK $18 \mu \mathrm{g} \mathrm{g}^{-1}$ (meningkat 80\%), dan kejenuhan Al 29\% (turun 45.28\%). Hanum (2013) dan Jaili dan Purwono (2016) menyatakan bahwa peran penting bahan organik terhadap sifat fisiko-kimia tanah adalah meningkatkan KTK dan $\mathrm{pH}$ tanah.

Tabel 3 menggambarkan nilai LTR perlakuan $\mathrm{K}_{3}$ lebih tinggi $8.88 \%$ dibanding $\mathrm{K}_{1}$ dan $6.52 \%$ dibandingkan $\mathrm{K}_{5}$. Produktivitas tanaman perlakuan $\mathrm{K}_{3}$ lebih tinggi $49.15 \%$ dibandingkan $\mathrm{K}_{1}$ dan $16.55 \%$ dibandingkan $\mathrm{K}_{5}$. Kandungan protein $\mathrm{K}_{3}$ lebih tinggi $15.45 \%$ dibandingkan $\mathrm{K}_{1}$ dan $17.36 \%$ dibandingkan $\mathrm{K}_{5}$. Fakta ini menunjukkan bahwa penggabungan hara organik dengan anorganik meningkatkan pertumbuhan, produktivitas, dan kualitas benih kedelai. Hasil percobaan ini didukung oleh pendapat Shaheen et al. (2017) bahwa penggunaan hara anorganik secara tunggal tidak mendukung pertumbuhan tanaman terutama pada lahan-lahan yang aktif dibudidayakan.

Laju tumbuh relatif dan produktivitas tanaman pada perlakuan $\mathrm{K}_{3}$ lebih tinggi $20.49 \%$ dan $134.66 \%$ dibandingkan $\mathrm{K}_{0}$ (Tabel 3). Pertumbuhan dan produktivitas tanaman pada $\mathrm{K}_{0}$ lebih rendah karena unsur hara yang ada di dalam tanah tidak tersedia optimal. Hasil analisis tanah menunjukkan kandungan hara terkategori rendah (Tabel 2). Menurut Nkoa et al. (2015), agar tumbuh dan berproduksi dengan baik, kedelai membutuhkan hara nitrogen sebesar $25 \mathrm{~kg} \mathrm{ha}^{-1}$, fosfor setara $\mathrm{P}_{2} \mathrm{O}_{5}$ sebanyak 50 sampai $60 \mathrm{~kg} \mathrm{ha}^{-1}$, dan kalium setara $\mathrm{K}_{2} \mathrm{O}$ sebanyak $50 \mathrm{~kg} \mathrm{ha}^{-1}$.

Tabel 2. Hasil analisis kesuburan lahan di lokasi percobaan

\begin{tabular}{|c|c|c|c|c|c|c|}
\hline No. & Sifat & Satuan & $\begin{array}{l}\text { Hasil analisis } \\
\text { tanah sebelum } \\
\text { percobaan } \\
\text { (Februari 2017) }\end{array}$ & & $\begin{array}{c}\text { Hasil analisis } \\
\text { tanah setelah } \\
\text { percobaan } \\
\text { (Juli 2017) }\end{array}$ & Kriteria* \\
\hline 1 & $\mathrm{pH}\left(\mathrm{H}_{2} \mathrm{O}\right) 1: 1$ & - & 5.00 & Masam & 6.30 & Agak masam \\
\hline 2 & C-organik & $\%$ & 1.05 & Sangat rendah & 2.20 & Sedang \\
\hline 3 & N-total & $\%$ & 0.08 & Sangat rendah & 0.28 & Sedang \\
\hline 4 & $\mathrm{P}_{2} \mathrm{O}_{5}$-Bray & $\mu \mathrm{g} \mathrm{g}^{-1}$ & 10.00 & Rendah & 16.00 & Sedang \\
\hline 5 & K-dd & $\mu \mathrm{g} \mathrm{g}^{-1}$ & 0.19 & Rendah & 0.28 & Rendah \\
\hline 6 & $\mathrm{Na}$ & $\mu \mathrm{g} \mathrm{g}^{-1}$ & 0.33 & Rendah & 0.40 & Sedang \\
\hline 7 & $\mathrm{Ca}$ & $\mu \mathrm{g} \mathrm{g}^{-1}$ & 0.44 & Sangat rendah & 0.45 & Sangat rendah \\
\hline 8 & $\mathrm{Mg}$ & $\mu \mathrm{g} \mathrm{g}^{-1}$ & 0.05 & Sangat rendah & 1.10 & Sedang \\
\hline 9 & KTK & $\mu \mathrm{g} \mathrm{g}^{-1}$ & 15.00 & Rendah & 18.00 & Sedang \\
\hline 10 & Kejenuhan Al & $\%$ & 53.00 & Tinggi & 29.00 & Sedang \\
\hline
\end{tabular}

Keterangan: *Kriteria berdasarkan Balai Penelitian Tanah (2005)

Tabel 3. Analisis pertumbuhan tanaman, produktivitas dan kualitas benih kedelai dari tanaman dengan perlakuan kombinasi hara organik dan anorganik

\begin{tabular}{lcccccc}
\hline Kode perlakuan & ILD & $\begin{array}{c}\text { LAB } \\
\left(\mathrm{mg} \mathrm{cm}^{-2}\right. \\
\text { per hari })\end{array}$ & $\begin{array}{c}\text { LTR } \\
\left(\mathrm{mg} \mathrm{g}^{-1} \text { per }\right. \\
\text { hari })\end{array}$ & $\begin{array}{c}\text { Produktivitas } \\
\left(\text { ton ha }^{-1}\right)\end{array}$ & $\begin{array}{c}\text { Bobot } \\
1,000 \text { butir } \\
(\mathrm{g})\end{array}$ & $\begin{array}{c}\text { Kandungan } \\
\text { protein } \\
(\%)\end{array}$ \\
\hline $\mathrm{K}_{0}($ Kontrol $)$ & $3.05 \mathrm{~d}$ & $5.67 \mathrm{c}$ & $1.22 \mathrm{c}$ & $0.75 \mathrm{~d}$ & $131.45 \mathrm{~d}$ & $36.46 \mathrm{c}$ \\
$\mathrm{K}_{1}(100 \%$ organik $)$ & $3.42 \mathrm{c}$ & $6.32 \mathrm{~b}$ & $1.35 \mathrm{~b}$ & $1.18 \mathrm{c}$ & $143.15 \mathrm{c}$ & $37.59 \mathrm{c}$ \\
$\mathrm{K}_{2}(75 \%$ organik $+25 \%$ anorganik $)$ & $3.88 \mathrm{ab}$ & $6.68 \mathrm{a}$ & $1.40 \mathrm{a}$ & $1.59 \mathrm{~b}$ & $146.68 \mathrm{a}$ & $39.13 \mathrm{~b}$ \\
$\mathrm{~K}_{3}(50 \%$ organik $+50 \%$ anorganik $)$ & $3.98 \mathrm{a}$ & $6.72 \mathrm{a}$ & $1.47 \mathrm{a}$ & $1.76 \mathrm{a}$ & $147.71 \mathrm{a}$ & $43.40 \mathrm{a}$ \\
$\mathrm{K}_{4}(25 \%$ organik $+75 \%$ anorganik $)$ & $4.02 \mathrm{a}$ & $6.70 \mathrm{a}$ & $1.46 \mathrm{a}$ & $1.72 \mathrm{a}$ & $143.45 \mathrm{c}$ & $43.89 \mathrm{a}$ \\
$\mathrm{K}_{5}(100 \%$ anorganik $)$ & $3.67 \mathrm{~b}$ & $6.45 \mathrm{~b}$ & $1.38 \mathrm{~b}$ & $1.51 \mathrm{~b}$ & $145.81 \mathrm{~b}$ & $36.98 \mathrm{c}$ \\
\hline
\end{tabular}

Keterangan: Angka-angka yang diikuti oleh huruf kecil yang sama tidak berbeda nyata menurut uji Duncan taraf $\alpha 0.05$. ILD = indeks luas daun; LAB = laju asimilasi bersih; LTR = laju tumbuh relatif 
Efektivitas penggunaan hara anorganik akan meningkat bila aplikasinya dikombinasikan dengan hara organik. Menurut Yagoub et al. (2015), penambahan hara organik akan meningkatkan kesuburan kimia lahan kering masam melalui dua fungsi penting, yakni (a) menurunkan unsur Al terlarut dan meningkatkan $\mathrm{pH}$, dan (b) sebagai sumber hara makro dan mikro. Kristiono dan Sambudi (2013) menyatakan bahwa aktivitas mikrobia tanah menjadi salah satu indikator kesuburan biologi tanah. Muzaiyanah dan Subandi (2016) menambahkan bahwa asam organik yang terkandung pada pupuk organik mampu menurunkan kejenuhan $\mathrm{Al}$ melalui mekanisme pengikatan $\mathrm{Al}$ monomer $\left(\mathrm{Al}^{3+}\right)$ sehingga $\mathrm{P}_{2} \mathrm{O}_{5}$ menjadi lebih tersedia.

\section{Kualitas Benih}

Kualitas benih menurun sejalan dengan waktu penyimpanan. Benih dari tanaman yang diberi perlakuan $\mathrm{K}_{3}$ penurunan kualitasnya paling rendah dibandingkan perlakuan lainnya sampai 3 BSS (Tabel 4).

Tabel 4 menunjukkan rata-rata penurunan kualitas benih bersifat konstan. Setelah 3 bulan disimpan, bobot

Tabel 4. Kualitas benih kedelai pada periode $0,1,2$, dan 3 bulan setelah simpan dari tanaman yang diberi perlakuan kombinasi hara organik dan anorganik

\begin{tabular}{|c|c|c|c|c|}
\hline \multirow{2}{*}{ Perlakuan tanaman induk } & \multicolumn{4}{|c|}{ Periode simpan (bulan) } \\
\hline & 0 & 1 & 2 & 3 \\
\hline & \multicolumn{4}{|c|}{ Bobot 1,000 butir benih $(\mathrm{g})$} \\
\hline $\mathrm{K}_{0}($ Kontrol $)$ & $131.45 \mathrm{c}$ & $130.12 \mathrm{c}$ & $129.34 \mathrm{c}$ & $126.87 \mathrm{c}$ \\
\hline $\mathrm{K}_{1}(100 \%$ organik $)$ & $143.15 b$ & $142.34 b$ & $140.95 b$ & $138.47 \mathrm{~b}$ \\
\hline $\mathrm{K}_{2}(75 \%$ organik $+25 \%$ anorganik $)$ & $146.68 \mathrm{a}$ & $145.72 \mathrm{a}$ & $142.41 \mathrm{a}$ & $140.12 \mathrm{a}$ \\
\hline $\mathrm{K}_{3}(50 \%$ organik $+50 \%$ anorganik $)$ & $147.71 \mathrm{a}$ & $146.68 \mathrm{a}$ & $143.32 \mathrm{a}$ & $140.98 \mathrm{a}$ \\
\hline $\mathrm{K}_{4}(25 \%$ organik $+75 \%$ anorganik $)$ & $143.45 b$ & $142.32 b$ & $142.41 \mathrm{a}$ & $140.11 \mathrm{a}$ \\
\hline $\mathrm{K}_{5}(100 \%$ anorganik $)$ & $145.81 \mathrm{a}$ & $144.25 \mathrm{ab}$ & $143.27 \mathrm{a}$ & $141.07 \mathrm{a}$ \\
\hline \multirow[t]{2}{*}{ Rata-Rata } & 143.04 & 141.91 & 140.28 & 137.94 \\
\hline & \multicolumn{4}{|c|}{ Kadar air (\%) } \\
\hline $\mathrm{K}_{0}($ Kontrol $)$ & $9.98 \mathrm{a}$ & $9.99 \mathrm{a}$ & $10.25 \mathrm{a}$ & $10.67 \mathrm{c}$ \\
\hline $\mathrm{K}_{1}(100 \%$ organik $)$ & $9.97 \mathrm{a}$ & $9.99 \mathrm{a}$ & $10.28 \mathrm{a}$ & $10.81 \mathrm{~b}$ \\
\hline $\mathrm{K}_{2}(75 \%$ organik $+25 \%$ anorganik $)$ & $9.89 \mathrm{a}$ & $10.10 \mathrm{a}$ & $10.35 \mathrm{a}$ & $10.88 \mathrm{a}$ \\
\hline $\mathrm{K}_{3}(50 \%$ organik $+50 \%$ anorganik $)$ & $9.97 \mathrm{a}$ & $10.15 \mathrm{a}$ & $10.45 \mathrm{a}$ & $10.82 \mathrm{~b}$ \\
\hline $\mathrm{K}_{4}(25 \%$ organik $+75 \%$ anorganik $)$ & $9.99 \mathrm{a}$ & $10.00 \mathrm{a}$ & $10.29 \mathrm{a}$ & $10.81 \mathrm{~b}$ \\
\hline $\mathrm{K}_{5}(100 \%$ anorganik $)$ & $10.00 \mathrm{a}$ & $10.02 \mathrm{a}$ & $10.25 \mathrm{a}$ & $10.82 b$ \\
\hline \multirow[t]{2}{*}{ Rata-Rata } & 9.97 & 10.04 & 10.31 & 10.80 \\
\hline & \multicolumn{4}{|c|}{ Protein $(\%)$} \\
\hline $\mathrm{K}_{0}$ (Kontrol) & $36.46 \mathrm{c}$ & $34.13 \mathrm{c}$ & $30.90 \mathrm{c}$ & $29.98 \mathrm{c}$ \\
\hline $\mathrm{K}_{1}(100 \%$ organik $)$ & $37.59 \mathrm{~b}$ & $35.59 \mathrm{~b}$ & $33.40 \mathrm{~b}$ & $32.23 b$ \\
\hline $\mathrm{K}_{2}(75 \%$ organik $+25 \%$ anorganik $)$ & $39.13 b$ & $37.7 b$ & $34.05 b$ & $33.43 \mathrm{ab}$ \\
\hline $\mathrm{K}_{3}(50 \%$ organik $+50 \%$ anorganik $)$ & $43.40 \mathrm{a}$ & $41.46 \mathrm{a}$ & $36.05 a$ & $34.98 \mathrm{a}$ \\
\hline $\mathrm{K}_{4}(25 \%$ organik $+75 \%$ anorganik $)$ & $43.89 \mathrm{a}$ & $41.89 \mathrm{a}$ & $36.19 \mathrm{a}$ & $34.79 \mathrm{a}$ \\
\hline $\mathrm{K}_{5}(100 \%$ anorganik $)$ & $36.98 \mathrm{c}$ & $34.27 \mathrm{~b}$ & $33.05 b$ & $32.12 b$ \\
\hline \multirow[t]{2}{*}{ Rata-Rata } & 39.58 & 37.51 & 33.94 & 32.92 \\
\hline & \multicolumn{4}{|c|}{ Daya hantar listrik $\left(\mu \mathrm{Scm}^{-1} \mathrm{~g}^{-1}\right)$} \\
\hline $\mathrm{K}_{0}$ (Kontrol) & $57.13 \mathrm{a}$ & $57.41 \mathrm{a}$ & $58.87 \mathrm{a}$ & $59.17 \mathrm{a}$ \\
\hline $\mathrm{K}_{1}(100 \%$ organik $)$ & $55.01 \mathrm{a}$ & $55.16 b$ & $52.01 \mathrm{c}$ & $54.98 \mathrm{c}$ \\
\hline $\mathrm{K}_{2}(75 \%$ organik $+25 \%$ anorganik $)$ & $55.43 \mathrm{a}$ & $55.87 \mathrm{~b}$ & $55.05 b$ & $57.25 b$ \\
\hline $\mathrm{K}_{3}(50 \%$ organik $+50 \%$ anorganik $)$ & $53.00 \mathrm{a}$ & $53.72 \mathrm{c}$ & $56.02 b$ & $57.42 b$ \\
\hline $\mathrm{K}_{4}(25 \%$ organik $+75 \%$ anorganik $)$ & $53.15 \mathrm{a}$ & $53.75 \mathrm{c}$ & $55.67 \mathrm{~b}$ & $56.58 \mathrm{bc}$ \\
\hline $\mathrm{K}_{5}(100 \%$ anorganik $)$ & $54.88 \mathrm{a}$ & $55.01 \mathrm{~b}$ & $55.89 \mathrm{~b}$ & $56.52 \mathrm{bc}$ \\
\hline Rata-Rata & 54.77 & 55.15 & 55.59 & 56.99 \\
\hline
\end{tabular}


1,000 butir benih turun $3.57 \%$ (dari 143.04 g menjadi 137.04 g), kadar air benih meningkat $8.43 \%$ (dari $9.97 \%$ menjadi $10.81 \%$ ), protein benih turun $16.83 \%$ (dari 39.58 menjadi $32.92 \%$ ), DHL meningkat $4.05 \%$ (dari $54.77 \mu \mathrm{Scm}^{-1} \mathrm{~g}^{-1}$ menjadi $56.99 \mu \mathrm{Scm}^{-1} \mathrm{~g}^{-1}$ ), daya berkecambah dan kecepatan tumbuh turun masing-masing $21.27 \%$ (dari 99.62\% menjadi $78.43 \%$ ), dan $32.92 \%$ (dari $38.70 \%$ etmal $^{-1}$ menjadi $25.96 \%$ etmal $^{-1}$ ). Penurunan kualitas benih yang konstan juga didapat oleh Mattioni et al. (2015) dan Noviana et al. (2016).

Setelah penyimpanan 3 bulan, bobot 1,000 butir benih pada perlakuan $\mathrm{K}_{3}(140.98 \mathrm{~g})$ lebih tinggi $11.12 \%$ dibandingkan perlakuan $\mathrm{K}_{0}(126.87 \mathrm{~g})$. Bobot benih yang tinggi akan meningkatkan luas permukaan kontak benih dengan uap air sehingga ada kecenderungan peningkatan kadar air benih selama penyimpanan. Kadar air benih perlakuan $\mathrm{K}_{3}$ meningkat $8.52 \%$, pada perlakuan $\mathrm{K}_{0}$ meningkat $7.71 \%$. Hal yang sama diperoleh oleh Anto dan Jayaram (2010) bahwa benih dengan ukuran besar memiliki kecenderungan peningkatan kadar air yang lebih tinggi. Peningkatan kadar air benih akan meningkatkan perombakan protein sehingga mendorong laju kebocoran ion.

Kandungan protein benih menurun selama penyimpanan. Pada perlakuan $\mathrm{K}_{3}$ menurun sebesar $21.61 \%$ dan perlakuan $\mathrm{K}_{0}$ menurun $24.07 \%$. Penyebab menurunnya kandungan protein pada benih kedelai yang disimpan berhubungan dengan reaksi oksidasi asam amino dan peningkatan kadar air. Kandungan protein yang tinggi pada membran sel akan meningkatkan integritas membran sel tersebut sehingga tidak mudah mengalami kebocoran. Menurut Bellaloui dan Gillen (2010) bahwa protein tersebar secara individual dan bersifat hidrofilik, tertanam dan menembus kedalam interior membran. Kebocoran membran sel terjadi karena protein yang tertanam dan terhubung dengan interior membran terdegradasi sehingga sel menjadi terbuka.

Membran sel yang terdegradasi akan meningkatkan kebocoran ion jika benih direndam dalam air. Peningkatan kebocoran ion benih perlakuan $\mathrm{K}_{3}$ setelah 3 BSS sebesar $8.34 \%$, pada perlakuan $\mathrm{K}_{0}$ meningkat $62.29 \%$. Hasil penelitian Noviana et al. (2016) menunjukkan peningkatan kebocoran ion sebesar $15.55 \%$ selama 6 BSS. Peningkatan ini termasuk rendah karena penyimpanan benih di ruang terkontrol pada suhu $19-22^{\circ} \mathrm{C}$. Hasil penelitian ini didukung oleh Mattioni et al. (2015), degradasi protein menyebabkan membran sel rusak sehingga kebocoran ion menjadi tinggi.

Daya berkecambah benih pada perlakuan $\mathrm{K}_{3}$ menurun sebesar $24.49 \%$, pada perlakuan $\mathrm{K}_{0}$ menurun sebesar $42.57 \%$. Kecepatan tumbuh benih pada perlakuan $\mathrm{K}_{3}$ menurun sebesar $39.05 \%$, pada perlakuan $\mathrm{K}_{0}$ menurun sebesar $65.06 \%$. Pada akhir penyimpanan, daya berkecambah dan kecepatan tumbuh benih pada perlakuan $\mathrm{K}_{3}$ dapat dipertahankan sebesar $80.08 \%$ dan $27.48 \%$ etmal $^{-1}$. Hasil percobaan ini menunjukkan bahwa benih kedelai dari perlakuan $\mathrm{K}_{3}$ memiliki laju penurunan daya berkecambah dan kecepatan tumbuh yang paling rendah dibandingkan perlakuan lainnya.

Tabel 4. Kualitas benih kedelai pada periode 0, 1, 2 dan 3 bulan setelah simpan dari tanaman yang diberi perlakuan kombinasi hara organik dan anorganik (lanjutan)

\begin{tabular}{|c|c|c|c|c|}
\hline \multirow{2}{*}{ Perlakuan tanaman induk } & \multicolumn{4}{|c|}{ Periode simpan (Bulan) } \\
\hline & 0 & 1 & 2 & 3 \\
\hline & \multicolumn{4}{|c|}{ Daya berkecambah (\%) } \\
\hline $\mathrm{K}_{0}$ (Kontrol) & $100.00 \mathrm{a}$ & $95.41 b$ & $81.14 d$ & $70.14 \mathrm{c}$ \\
\hline $\mathrm{K}_{1}(100 \%$ organik $)$ & $98.32 \mathrm{a}$ & $95.32 b$ & $90.75 a$ & $78.75 b$ \\
\hline $\mathrm{K}_{2}(75 \%$ organik $+25 \%$ anorganik $)$ & $100.00 \mathrm{a}$ & $97.45 \mathrm{a}$ & $83.42 \mathrm{c}$ & $79.42 b$ \\
\hline $\mathrm{K}_{3}(50 \%$ organik $+50 \%$ anorganik $)$ & $100.00 \mathrm{a}$ & $96.67 \mathrm{a}$ & $84.98 \mathrm{c}$ & $80.98 \mathrm{a}$ \\
\hline $\mathrm{K}_{4}(25 \%$ organik $+75 \%$ anorganik $)$ & $99.72 \mathrm{a}$ & $95.54 b$ & $83.73 c$ & $80.73 \mathrm{a}$ \\
\hline $\mathrm{K}_{5}(100 \%$ anorganik $)$ & $99.68 \mathrm{a}$ & $95.56 \mathrm{~b}$ & $85.53 b$ & $80.53 \mathrm{a}$ \\
\hline \multirow[t]{2}{*}{ Rata-Rata } & 99.62 & 95.99 & 84.93 & 78.43 \\
\hline & \multicolumn{4}{|c|}{ Kecepatan berkecambah $\left(\%\right.$ etmal $\left.^{-1}\right)$} \\
\hline $\mathrm{K}_{0}$ (Kontrol) & $38.97 \mathrm{a}$ & $38.45 \mathrm{a}$ & $27.45 \mathrm{c}$ & $23.61 \mathrm{~b}$ \\
\hline $\mathrm{K}_{1}(100 \%$ organik $)$ & $38.64 \mathrm{a}$ & $38.32 \mathrm{a}$ & $32.74 \mathrm{a}$ & $24.32 \mathrm{~b}$ \\
\hline $\mathrm{K}_{2}(75 \%$ organik $+25 \%$ anorganik $)$ & $38.92 \mathrm{a}$ & $38.81 \mathrm{a}$ & $30.34 b$ & $25.41 \mathrm{~b}$ \\
\hline $\mathrm{K}_{3}(50 \%$ organik $+50 \%$ anorganik $)$ & $38.21 \mathrm{a}$ & $37.98 \mathrm{a}$ & $30.76 b$ & $27.48 \mathrm{a}$ \\
\hline $\mathrm{K}_{4}(25 \%$ organik $+75 \%$ anorganik $)$ & $38.65 \mathrm{a}$ & $38.45 \mathrm{a}$ & $29.54 b$ & $27.32 \mathrm{a}$ \\
\hline $\mathrm{K}_{5}(100 \%$ anorganik $)$ & $38.81 \mathrm{a}$ & $38.72 \mathrm{a}$ & $30.23 b$ & $27.61 \mathrm{a}$ \\
\hline Rata-Rata & $38.7 \mathrm{a}$ & 38.46 & 30.18 & 25.96 \\
\hline
\end{tabular}

Keterangan: Angka-angka yang diikuti oleh huruf kecil yang sama tidak berbeda nyata menurut uji Duncan taraf $\alpha 0.05$ 


\section{KESIMPULAN}

Kombinasi hara organik dan anorganik pada perlakuan $\mathrm{K}_{3}$ menghasilkan benih sebanyak 1.76 ton ha-1, bobot 1,000 butir sebesar $147.47 \mathrm{~g}$ dan kandungan protein sebanyak $43.40 \%$. Benih yang berasal dari tanaman yang diberi perlakuan $\mathrm{K}_{3}$ menunjukkan kualitas benih yang masih baik saat memasuki periode simpan alami selama 3 BSS dengan indikator bobot 1,000 butir benih $140.98 \mathrm{~g}$, kadar air $10.82 \%$, kandungan protein $34.98 \%$, DHL 57.42 $\mu \mathrm{Scm}^{-1} \mathrm{~g}^{-1}$, daya berkecambah $80.98 \%$ dan kecepatan tumbuh $27.48 \%$ etmal $^{-1}$. Kompos serasah kedelai sebanyak 2.5 ton dapat mensubstitusi penggunaan hara anorganik sebanyak $50 \%$ dan merupakan salah satu upaya menciptakan proses produksi bersih dalam produksi benih kedelai.

\section{UCAPAN TERIMA KASIH}

Terima kasih disampaikan kepada Direktur Riset dan Pengabdian Masyarakat Kementerian Ristekdikti atas bantuan dana dalam pelaksanaan penelitian ini.

\section{DAFTAR PUSTAKA}

Anto, K.B., K.M. Jayaram. 2010. Effect of temperature treatment on seed water content and viability of green pea (Pisum sativum L.) and soybean (Glycine max L. Merr.) seeds. Int. J. Bot. 6:122-126.

Balai Penelitian Tanaman Aneka Kacang dan Umbi. 2018. Tahun 2018 tahun kedelai. http://balitkabi.litbang. pertanian.go.id [30 April 2018].

Balai Penelitian Tanah. 2005. Petunjuk Teknis Analisis Kimia Tanah, Tanaman, Air dan Pupuk. Balai Penelitian Tanah, Departemen Pertanian, Bogor, ID.

Bellaloui, N., A.M. Gillen. 2010. Soybean seed protein, oil, fatty acids, $\mathrm{N}$, and $\mathrm{S}$ partitioning as affected by node position and cultivar differences. Agric. Sci. 1:110118.

Garud, C.B., S.B. Borgaonkar, B.N. Chinchane. 2014. Correlation and path analysis of seed quality characters in Soybean. Int. J. Plant Sci. 9:293-294.

Hanum, C. 2013. Pertumbuhan, hasil, dan mutu biji kedelai dengan pemberian pupuk organik dan fosfor. J. Agron. Indonesia 41:209-214.

Hartawan, R., Y. Nengsih., E. Marwan. 2017. Pemanfaatan serasah kedelai sebagai bahan kompos. hal. 89-91. Dalam Faridah, Rachmawati, Suryati, Harzukil (Eds.) Prosiding Seminar Nasional Politeknik Nengeri Lhokseumawe. Lhokseumawe 1 September 2017.

Jaili, M.A.B., Purwono. 2016. Pengurangan dosis pupuk anorganik dengan pemberian kompos blotong pada budi daya tanaman tebu (Saccharum officinarum L.) lahan kering. Bul. Agrohorti 4:113-121.

Kristiono, A., Sambudi. 2013. Evaluasi efektivitas pupuk organik untuk tanaman kedelai di lahan kering masam. hal. 49-58. Dalam N. Saleh, A. Harsono, N. Nugrahaeni, A.A. Rahmiana, Solihin, M. Jusuf, Herianto, I.K. Tastra, M.M. Adie, Hermanto, D. Harnowo (Eds.). Prosiding Seminar Hasil Penelitian Tanaman Aneka Kacang dan Umbi. Malang 22 Mei 2013.

Kurnia, V.C., S. Sumiyati, G. Samudro. 2017. Pengaruh kadar air terhadap hasil pengomposan sampah organik dengan metode open wind row. J. Teknik Mesin 6:58-62.

Mattioni, N.M., L.L. Mertz, A.P.P. Barbieri, F.M. Haesbaert, W. Giordani, S.J. Lopes. 2015. Individual electrical conductivity test for the assessment of soybean seed germination. Ciênc. Agrár. 36:31-38.

Muhammad, A., S.K. Khalil, A.Z. Khan, Amanullah, S. Mehmood. 2013. Growth analysis of indigenous soybean land races. Pak. J. Bot. 45:941-949.

Muzaiyanah, S., Subandi. 2016. Peranan bahan organik dalam peningkatan produksi kedelai dan ubi kayu pada lahan kering masam. Iptek Tan. Pangan 11:149157.

Nkoa, R., B. Ondoua, P. Voroney, J. Tambong. 2014. Evidence of the interaction between crop species and organic amendments: modelling of the differential grain yield response of wheat, soybean, and canola to organic amendments. Sustainable Agric. Res. 3:3345.

Noviana, I., A. Qadir, F.C. Suwarno. 2016. Perilaku biokimia benih kedelai selama penyimpanan dalam kondisi terkontrol. J. Agron. Indonesia 44:255-260.

Rastegar, Z., M. Sedghi, S. Khomari. 2011. Effects of accelerated aging on soybean seed germination indexes at laboratory conditions. Not. Sci. Biol. 3:126-129.

Shaheen, A., R. Tariq, A. Khaliq. 2017. Comparative and interactive effects of organic and inorganic amendments on soybean growth, yield and selected soil properties. Asian J. Agri. Biol. 5:60-69.

Yagoub, S.O., A.S.K.A. Salam, M. M. Hassan, M. A. Hassan. 2015. Effects of organic and mineral fertilizers on growth and yield of soybean (Glycine max L. Merril). IJAAR. 7:45-52. 